\title{
Pemetaan Status Kerusakan Tanah Lahan Pertanian di Kecamatan Selo, Kabupaten Boyolali
}

\section{Mapping Status of Soil Damage on Agricultural Land at Selo District, Boyolali Regency}

\author{
Kholishotu Syahidah $^{1)}$, Sumarno ${ }^{2)}$, Sri Hartati ${ }^{2)}$
}

\begin{abstract}
Intensively land use for biomass production without applying sustainable and sustained plant farming technique in District Selo potentially causes soil damage. Determination of soil potential damage and soil damage status has been set by the central government through Government Regulation No. 150 year 2000 on Soil Damage Control for Biomass Production. The research method used was a descriptive survey with a stage-setting soil potential damage by overlay thematic maps and the determination of the status of soil damage using matching methods and relative frequency score. Results obtained in the land area of the District Selo potentially medium damage 1,439.3 hectares and 1,988.8 hectares of high potential damage. After survey and laboratory analysis of soil samples at the site results that the Status of Soil Damage categorized light (R.I) with a score relative frequency of each 8. Total area that included minor damage divided into 3,296.97 hectares with limiting factors texture and permeability and 59.32 hectares with limiting factors permeability.
\end{abstract}

Keywords : soil degradation, land use, biomass

\section{PENDAHULUAN}

Peningkatan berbagai usaha pertanian dalam berbagai aspeknya telah mempengaruhi sifat dasar tanah. Pada tahun 2013 di Kecamatan Selo tercatat sebanyak 6.071 jiwa bekerja di sektor pertanian tanaman pangan, 766 jiwa di sektor peternakan dan 9.400 jiwa di sektor pertanian lainnya (BPS Kec. Selo 2013). Penggunaan lahan untuk produksi biomassa secara intensif tanpa menerapkan teknik budidaya tanaman secara lestari dan berkelanjutan di Kecamatan Selo berpotensi menyebabkan kerusakan tanah.

Suriadi dan Nazam (2005), menyebutkan bahwa dampak negatif dari ketidakmampuan tanah untuk memenuhi fungsinya adalah terganggunya kualitas tanah sehingga menimbulkan bertambah luasnya lahan kritis, menurunnya produktivitas tanah dan pencemaran lingkungan. Oleh karena itu, diperlukan studi tentang status kerusakan tanah suatu wilayah untuk menjadi dasar penentu tindakan pengelolaan tanah dan lahan yang sesuai, sehingga kerusakan tanah dapat dicegah dan/atau diperbaiki. Penelitian ini bertujuan memetakan potensi dan status kerusakan tanah untuk produksi biomassa di Kecamatan Selo. Status Kerusakan Tanah telah diatur oleh pemerintah pusat melalui Peraturan Pemerintah Nomor 150 Tahun 2000 tentang Pengendalian Kerusakan Tanah untuk Produksi Biomassa.

\section{METODE PENELITIAN}

Penelitian ini dilaksanakan pada bulan April September 2014 di Kecamatan Selo, Boyolali serta

1) Undergraduate Student of Study Program of Agrotechnology, Faculty of Agriculture University of Sebelas Maret (UNS) in Surakarta.

2) Lecturer Staff of Study Program of Agrotechnology, Faculty of Agriculture University of Sebelas Maret (UNS) in Surakarta.

Contact Author: sumarno_fpuns@yahoo.com analisis laboratorium di Laboratorium Fisika dan Konservasi Tanah, Laboratorium Kimia dan Kesuburan Tanah serta Laboratorium Biologi dan Kesehatan Tanah Fakultas Pertanian Universitas Sebelas Maret.

Bahan yang digunakan dalam penelitian ini yaitu Peta Tematik, sampel tanah lokasi penelitian (terusik dan tidak terusik) dan khemikalia untuk analisis laboratorium. Alat yang digunakan yaitu GPS, belati, klinometer, kompas, meteran, bor tanah, cangkul, raffia, alat tulis, form isian data kondisi tanah, plastik, ring sampel, kertas label, dan alat-alat untuk analisis laboratorium.

Metode penelitian yang digunakan adalah survei deskriptif dengan tahapan penetapan peta potensi kerusakan tanah hasil overlay peta tematik dan penetapan status kerusakan tanah menggunakan metode matching dan skor frekuensi relatif. Parameter yang digunakan meliputi data ketebalan solum, kebatuan permukaan, tekstur tanah, berat volume, porositas total, permeabilitas, $\mathrm{pH}$ tanah, daya hantar listrik, nilai redoks tanah, jumlah mikrobia, dan lapisan tanah tererosi.

\section{HASIL DAN PEMBAHASAN}

\section{Potensi Kerusakan Tanah}

Wilayah penelitian difokuskan pada areal kerja efektif. Hasil penyaringan daerah kerja efektif Kecamatan Selo melalui overlay dengan Peta Rencana Tata Ruang dan Wilayah didapatkan bahwa wilayah yang termasuk areal kerja efektif seluas 3.356,27 ha atau 55,34 \%, sedangkan wilayah yang merupakan bukan wilayah efektif (BWE) seluas $2.708,93$ ha atau $44,66 \%$.

Hasil overlay peta tematik yang telah dilakukan skoring (Gambar 1) diperoleh hasil bahwa terdapat 13 Satuan Peta Lahan (SPL) di Kecamatan Selo dengan kelas potensi kerusakan tanah sedang dan tinggi. 4 SPL termasuk dalam kelas kerusakan tanah sedang (PR III) yaitu SPL 1, SPL 2, SPL 7, dan SPL 9. 
Sedangkan 9 SPL dalam kelas kerusakan tanah tinggi (PR IV) yaitu SPL 3, SPL 4, SPL 5, SPL 6, SPL 8, SPL 10, SPL 11, SPL 12, dan SPL 13.

Wilayah yang berpotensi rusak sedang seluas $1.439,3$ ha atau $23,14 \%$ tersebar pada Tlogolele, Klakah, Jrakah, Senden, Jeruk, dan sedikit di Tarubatang dan Selo. Wilayah yang berpotensi rusak tinggi seluas $1.988,8$ ha atau $32,2 \%$ tersebar pada Samiran, Suroteleng, Lencoh, dan sedikit di Desa Jrakah, Tarubatang, Selo, Senden, dan Jeruk. Wilayah dengan potensi kerusakan tinggi didominasi dengan jenis tanah Andisol, kemiringan 16-25\% sampai $>40 \%$, curah hujan 3000-4000 mm/tahun, serta penggunaan lahan kebun dan tegalan. Sedangkan wilayah dengan potensi kerusakan sedang memiliki jenis tanah Andisol dan tanah Entisol, kemiringan 9-15\%, curah hujan 2000-3000 $\mathrm{mm} / \mathrm{tahun}$ dan 3000-4000 mm/tahun, serta penggunaan lahan sawah dan tegalan.

Jenis tanah Entisol memiliki potensi rusak tinggi, sedangkan tanah Andisol memiliki potensi rusak sangat tinggi. Rajiman (2014), menyebutkan tanah yang tersusun oleh pasir akan lebih banyak mengalami kerusakan dibandingkan dengan tanah yang disusun oleh klei. Kerusakan tanah menurut jenis tanah berdasakan pada tingkat ordo. Tanah yang tersusun oleh partikel klei tinggi cenderung memiliki potensi kerusakan rendah, sedangkan tanah yang telah mengalami perkembangan tingkat lanjut cenderung memiliki potensi kerusakan yang tinggi.
Kelerengan mempengaruhi kerusakan lahan terkait dengan besarnya erosi dan kemampuan tanah menyimpan air hujan. Semakin besar kelerengan akan menyebabkan kerusakan tanah yang makin tinggi. Potensi kerusakan berdasarkan kelerengan pada wilayah penelitian mulai dari ringan sampai sangat tinggi. Curah hujan pada wilayah penelitian tergolong kelas potensi kerusakan sedang dan tinggi. Tingginya curah hujan berkaitan dengan besarnya erosi tanah. Rajiman (2014) menyebutkan hujan yang turun akan mengenai tanah dan menghancurkan agregat tanah, kemudian terangkut ke tempat lain. Hujan yang sampai ke permukaan tanah akan mengalami infiltrasi, aliran permukaan, intersepsi dan penguapan. Aliran permukaan (run off) menyebabkan erosi akan meningkat.

Penilaian potensi kerusakan tanah berdasarkan penggunaan lahan didekati dengan mengacu pada koefisien tanaman (factor $\mathrm{C}$ ). Vegetasi yang nampak di permukaan tanah mencerminkan besarnya penutupan lahan oleh tajuk tanaman. Semakin banyak lahan yang tertutup, kerusakan tanah akan semakin kecil dan sebaliknya lahan yang semakin terbuka akan menyebabkan tanah memiliki potensi kerusakan yang besar. Penggunaan lahan yang ada pada wilayah penelitian yaitu hutan alam, sawah, kebun, hutan produksi dan tegalan dengan urutan potensi kerusakan tanah dari sangat rendah sampai tinggi

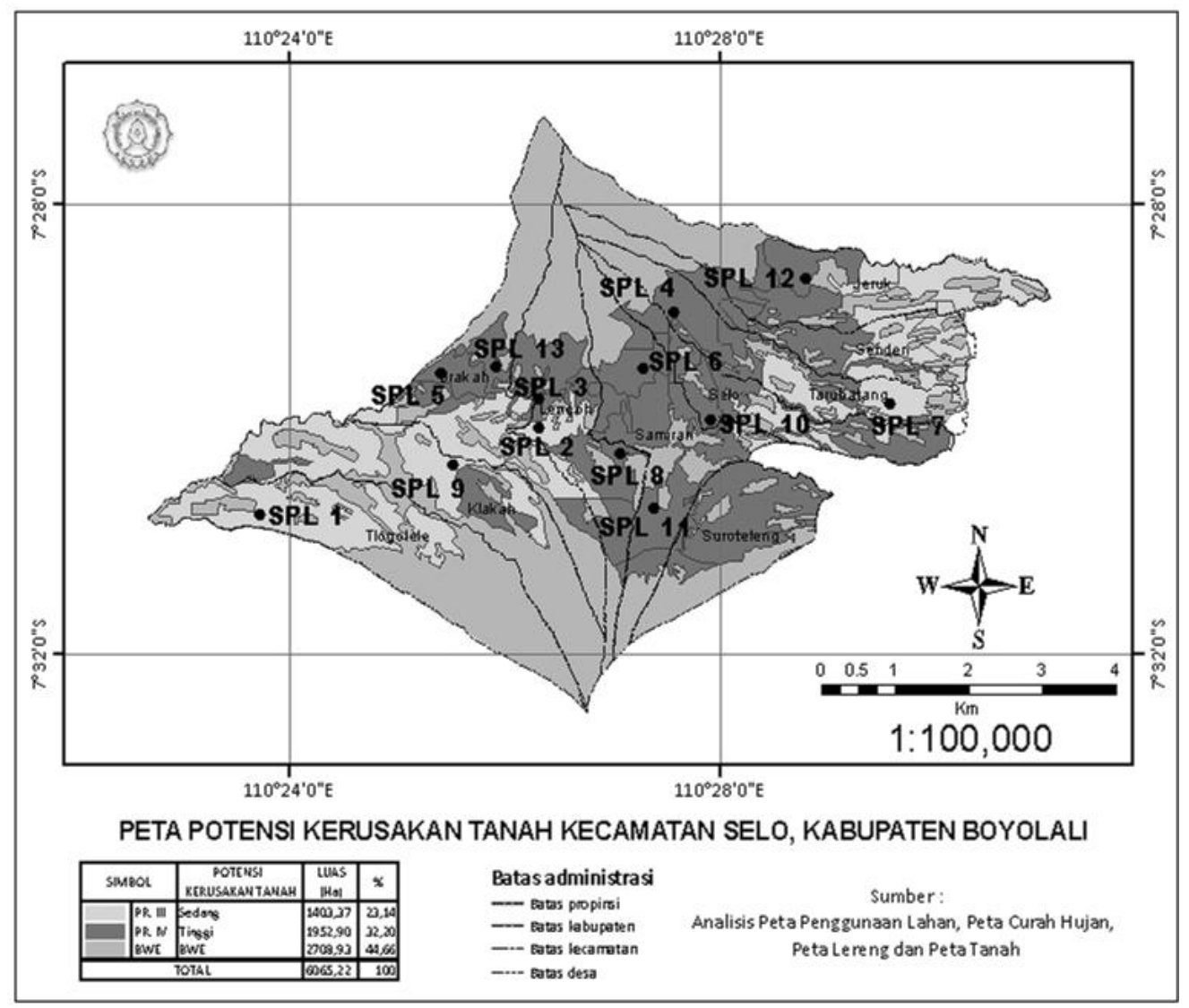

Gambar 1. Peta potensi kerusakan tanah Kecamatan Selo 


\section{Status Kerusakan Tanah}

Peta Status Kerusakan Tanah (Gambar 2.) untuk produksi biomassa disusun melalui dua tahapan yaitu matching dan skoring. Matching adalah membandingkan antara data parameter-parameter kerusakan tanah yang terukur dengan kriteria baku kerusakan tanah (sesuai dengan PP No. 150 tahun 2000). Melalui metode ini, setiap titik pengamatan dapat dikelompokan ke dalam tanah yang tergolong rusak (R) atau tidak rusak $(\mathrm{N})$. Hasil verifikasi lapangan karakteristik fisik lahan disajikan dalam Tabel 1.

Berdasarkan metode matching (Tabel 2), hasil analisis tekstur menunjukkan dominasi fraksi pasir sehingga dapat digolongkan dalam tanah berpasir. Menurut Rajiman (2014), tanah berpasir merupakan tanah yang memiliki kandungan pasir $>20 \%$, sehingga tanah terasa kasar dan tidak lekat. Golongan tanah ini memiliki sifat meluluskan air tinggi yang mengakibatkan kehilangan hara juga menjadi tinggi.

Oleh karena itu, ke-12 SPL untuk parameter tekstur tergolong dalam kategori rusak. Dominasi raksi debu dan pasir dengan kandungan fraksi klei cukup rendah merupakan akibat dari bahan induk yang terdiri dari kumulatif deposit abu vulkan. Hal ini sejalan dengan penelitian Siradz (2006) yang menjelaskan bahwa rendahnya kandungan fraksi klei pada tanah bukan merupakan akibat dari tindakan pengelolaan produksi biomassa melainkan merupakan konsekuensi dari bahan induk tanah.
Tekstur tanah menurut Hanafiah (2005) akan mempengaruhi pertumbuhan dan produksi tanaman, dibuktikan melalui penelitiannya yaitu pengaruh tekstur terhadap produksi pada tanaman jagung dan kentang. Hasilnya menunjukkan bahwa jagung tumbuh/berproduksi ideal pada tanah bertekstur klei, sedangkan kentang tumbuh ideal pada tanah bertekstur klei berpasir daripada yang bertekstur klei dan pasir berklei.

Analisis permeabilitas pada ke-13 pewakil SPL wilayah penelitian menunjukkan hasil di atas ambang kritis atas $(>8 \mathrm{~cm} / \mathrm{jam})$. Nilai permeabilitas tanah sangat dipengaruhi oleh sifat fisika tanah. Yulnafatmawita et al. (2007) menyebutkan beberapa sifat fisik tanah yang mempengaruhi nilai permeabilitas yaitu tekstur tanah, kandungan bahan organik tanah, dan porositas tanah.

Tanah di wilayah penelitian didominasi oleh fraksi pasir sehingga tanah menjadi sangat mudah dalam meloloskan air. Hal ini sesuai dengan pernyataan Hanafiah (2005) yang menyatakan bahwa tanah yang mengandung persentase pasir cukup besar dalam teksturnya akan mudah melewatkan air dalam tanah. Subroto (2010) dalam hasil penelitiannya menyebutkan bahwa kadar klei yang tinggi menunjukkan nilai permeabilitas yang semakin kecil/lambat dibandingkan pada kadar klei yang lebih rendah.

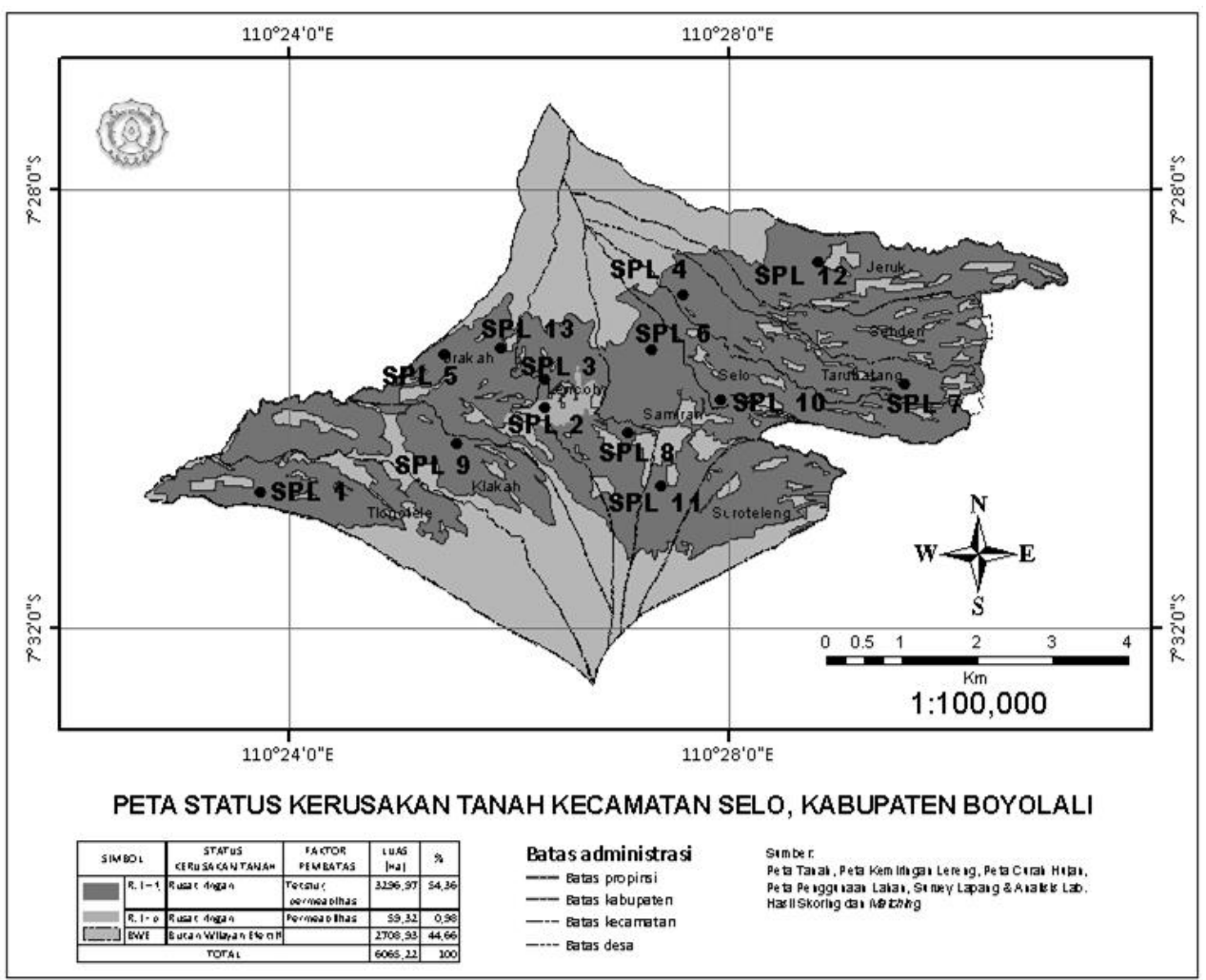

Gambar 2. Peta status kerusakan tanah Kecamatan Selo 
Tabel 1. Hasil verifikasi lapangan karakteristik fisik lahan lokasi sampel

\begin{tabular}{|c|c|c|c|c|c|c|c|c|}
\hline SPL & Letak Titik & Dusun & $\begin{array}{c}\text { Penggunaan } \\
\text { Lahan }\end{array}$ & Vegetasi & $\begin{array}{l}\text { Lereng } \\
(\%)\end{array}$ & $\begin{array}{l}\text { Panjang } \\
\text { lereng }(\mathrm{m})\end{array}$ & Erosi & Tindakan Konservas \\
\hline 1 & $\begin{array}{l}07^{\circ} 30^{\prime} 725^{\prime \prime} \text { LU } \\
110^{\circ} 23^{\prime} 748^{\prime \prime} \text { BT }\end{array}$ & Tlogolele & $\begin{array}{l}\text { Kebun } \\
\text { Campuran }\end{array}$ & $\begin{array}{l}\text { ketela pohon, kol, } \\
\text { buncis, cabe, } \\
\text { sengon, nangka }\end{array}$ & 11 & 7 & $\begin{array}{l}\text { Tanpa } \\
\text { erosi }\end{array}$ & Teras Bangku \\
\hline 2 & $\begin{array}{l}07^{\circ} 29^{\prime} 989^{\prime \prime} \text { LU } \\
110^{\circ} 26^{\prime} 436^{\prime \prime} \text { BT }\end{array}$ & Lencoh & Tegalan & $\begin{array}{l}\text { tembakau, ketela } \\
\text { rambat, lumpung, } \\
\text { adas, kol }\end{array}$ & 15 & 18 & Alur & Teras tradisional \\
\hline 3 & $\begin{array}{l}07^{\circ} 29^{\prime} 596 " \text { LU } \\
110^{\circ} 26^{\prime} 482 \mathrm{BT}\end{array}$ & Lencoh & Tegalan & $\begin{array}{l}\text { wortel, adas, } \\
\text { lompong, pisang, } \\
\text { rumput gajah }\end{array}$ & 16 & 7 & Alur & Teras tradisional \\
\hline 4 & $\begin{array}{l}07^{\circ} 28^{\prime} 55,3^{\prime \prime} \text { LU } \\
110^{\circ} 27^{\prime} 33,7 \mathrm{BT}\end{array}$ & Tarubatang & Hutan Alam & $\begin{array}{l}\text { pinus, tengsek, } \\
\text { rumput }\end{array}$ & 29 & 15 & Alur & $\begin{array}{l}\text { Tanpa tindakan } \\
\text { konservasi }\end{array}$ \\
\hline 5 & $\begin{array}{l}07^{\circ} 29^{\prime} 524^{\prime \prime} \mathrm{LU} \\
110^{\circ} 25^{\prime} 376 \mathrm{BT}\end{array}$ & Jrakah & $\begin{array}{l}\text { Hutan } \\
\text { Produksi }\end{array}$ & $\begin{array}{l}\text { cemara, rumput } \\
\text { gajah, bambu, } \\
\text { akasia, keduren }\end{array}$ & 32 & 6 & $\begin{array}{l}\text { Tanpa } \\
\text { erosi }\end{array}$ & Teras tradisional \\
\hline 6 & $\begin{array}{l}07^{\circ} 29^{\prime} 365^{\prime \prime} \mathrm{LU} \\
110^{\circ} 27^{\prime} 520 \mathrm{BT}\end{array}$ & Samiran & $\begin{array}{l}\text { Hutan } \\
\text { Produksi }\end{array}$ & $\begin{array}{l}\text { rumput gajah, } \\
\text { semak }\end{array}$ & 55 & 7 & Parit & $\begin{array}{l}\text { Tanpa tindakan } \\
\text { konservasi }\end{array}$ \\
\hline 7 & $\begin{array}{l}07^{\circ} 29^{\prime} 48,7^{\prime \prime} \mathrm{LU} \\
110^{\circ} 29^{\prime} 34,5 \mathrm{BT}\end{array}$ & Tarubatang & Tegalan & $\begin{array}{l}\text { tembakau, bawang } \\
\text { merah, wortel, } \\
\text { tomat }\end{array}$ & 12 & 20 & Alur & Teras tradisional \\
\hline 8 & $\begin{array}{l}07^{\circ} 30^{\prime} 135^{\prime \prime} \text { LU } \\
110^{\circ} 27^{\prime} 162 \mathrm{BT}\end{array}$ & Lencoh & Tegalan & $\begin{array}{l}\text { wortel, tembakau, } \\
\text { cabai, daun } \\
\text { bawang, pisang }\end{array}$ & 13 & 7 & Alur & Teras Bangku \\
\hline 9 & $\begin{array}{l}07^{\circ} 30^{\prime} 239 ” \text { LU } \\
110^{\circ} 25^{\prime} 439 \mathrm{BT}\end{array}$ & Klakah & Tegalan & $\begin{array}{l}\text { sawi, tembakau, } \\
\text { ketela pohon, daun } \\
\text { bawang }\end{array}$ & 11 & 8 & Alur & Teras Bangku \\
\hline 10 & $\begin{array}{l}07^{\circ} 29^{\prime} 987^{\prime \prime} \mathrm{LU} \\
110^{\circ} 27^{\prime} 917 \mathrm{BT}\end{array}$ & Selo & Tegalan & $\begin{array}{l}\text { tembakau, wortel, } \\
\text { adas, rumput } \\
\text { gajah, pinus, } \\
\text { sengon }\end{array}$ & 20 & 41 & Alur & Teras irigasi \\
\hline 11 & $\begin{array}{l}07^{\circ} 30^{\prime} 507^{\prime \prime} \text { LU } \\
110^{\circ} 27^{\prime} 413 \text { BT }\end{array}$ & Samiran & Tegalan & $\begin{array}{l}\text { tembakau, } \\
\text { wortel,jagung, } \\
\text { ketela rambat }\end{array}$ & 17 & 10 & Alur & Teras Bangku \\
\hline 12 & $\begin{array}{l}07^{\circ} 28^{\prime} 40,3^{\prime \prime} \text { LU } \\
110^{\circ} 28^{\prime} 47,3 \text { BT }\end{array}$ & Jeruk & Tegalan & $\begin{array}{l}\text { wortel, tembakau, } \\
\text { sawi sendok }\end{array}$ & 31 & 15 & Parit & Teras tradisional \\
\hline 13 & $\begin{array}{l}07^{\circ} 24^{\prime} 29,3^{\prime \prime} \text { LU } \\
110^{\circ} 25^{\prime} 57,0 \text { BT }\end{array}$ & Jrakah & Tegalan & $\begin{array}{l}\text { sawi hijau, kol, } \\
\text { singkong, teh }\end{array}$ & 32 & 11 & Parit & Teras tradisional \\
\hline
\end{tabular}

Berdasarkan struktur tanahnya, tanah lokasi penelitian memiliki struktur yang remah sehingga memiliki ruang pori yang lebih banyak dibandingkan dengan tanah yang padat sehingga berpengaruh terhadap porositas. Besarnya nilai porositas tanah ini berbanding lurus dengan laju permeabilitas. Kondisi ini sejalan dengan hasil penelitian Siregar et al. (2013) bahwa laju permeabilitas tanah Inceptisol lebih besar dibandingkan tanah Andepts dan Ultisol disebabkan oleh porositas tanah tersebut lebih besar dibandingkan porositas pada tanah Andepts dan Ultisol. Hanafiah (2005) menyatakan bahwa pori sangat menentukan sekali dalam permeabilitas tanah, semakin besar pori dalam tanah maka semakin cepat pula permeabitas tanah tersebut.

Berdasarkan nilai permeabilitas, tanah pada wilayah penelitian tergolong rusak sehingga diperlukan upaya untuk menurunkan nilai permeabilitas tanah. Cara yang dapat dilakukan untuk menurunkan laju permeabilitas tanah yaitu dengan menambahkan bahan organik tanah dan tanah dengan dominasi fraksi klei. Menurut Yulnafatmawita et al. (2007), penambahan bahan organik tanah akan memperbaiki struktur tanah sehingga tanah dapat memiliki kemampuan mengikat air yang tinggi dan penambahan klei ke dalam tanah akan meningkatkan total ruang pori yang didominasi oleh pori yang berukuran kecil, sehingga mampu mengurangi laju permeabilitas. Hal tersebut terjadi karena klei lebih mampu memegang dan menahan air daripada pasir.

Hasil dari metode matching berguna untuk tahapan selanjutnya, yaitu menentukan skor dan penetapan status kerusakan tanah berdasarkan frekuensi relatif. Dalam Tabel 3., hasil penjumlahan dari skor frekuensi relatif adalah 8 . Status kerusakan tanah berdasarkan nilai akumulasi skor kerusakan tanah, skor delapan (8) termasuk dalam Rusak Ringan (R.I).

Luas wilayah dengan Status Kerusakan Tanah Rusak Ringan (R.I) di Kecamatan Selo sebesar $3.356,29$ ha yang terbagi menjadi $3.296,97$ ha atau $54,36 \%$ dengan faktor pembatas tekstur dan permeabilitas dan 59,32 ha atau $0,98 \%$ dengan faktor pembatas permeabilitas. SPL 1 dan SPL 3-13 tergolong dalam kelas status rusak ringan dengan faktor pembatas tekstur dan permeabilitas, SPL 2 tergolong kelas status rusak ringan dengan faktor pembatas permeabilitas. 
Tabel 2. Hasil metode matching daerah penelitian

\begin{tabular}{|c|c|c|c|c|c|c|c|c|c|c|c|c|c|c|c|c|}
\hline \multirow{3}{*}{ SPL } & \multicolumn{16}{|c|}{ Parameter/ Simbol } \\
\hline & \multirow{2}{*}{\multicolumn{2}{|c|}{$\begin{array}{l}\text { Solum } \\
\text { Tanah } \\
(\mathrm{cm})\end{array}$}} & \multirow{2}{*}{\multicolumn{2}{|c|}{$\begin{array}{c}\text { Batuan } \\
\text { Permukaan } \\
(\%)\end{array}$}} & \multicolumn{2}{|c|}{ Tekstur (\%) } & \multirow{2}{*}{$\begin{array}{c}\text { BV } \\
\left(\mathrm{g} / \mathrm{cm}^{3}\right. \\
)\end{array}$} & \multirow{2}{*}{\multicolumn{2}{|c|}{$\begin{array}{l}\text { Porositas } \\
\text { Total (\%) }\end{array}$}} & \multirow{2}{*}{$\begin{array}{l}\text { Permeabilita } \\
\mathrm{s}(\mathrm{cm} / \mathrm{jam})\end{array}$} & \multirow{2}{*}{\multicolumn{2}{|c|}{ ita $\underset{\text { i) }}{\mathrm{pH}}$}} & \multirow{2}{*}{$\begin{array}{c}\mathrm{DHL} \\
(\mathrm{mS} / \mathrm{cm}\end{array}$} & \multirow{2}{*}{$\begin{array}{l}\text { Redoks } \\
(\mathrm{mV})\end{array}$} & \multirow{2}{*}{$\begin{array}{c}\text { Mikrobia } \\
\left(\times 10^{6}\right. \\
\mathrm{cfu} / \mathrm{g})\end{array}$} & \multirow{2}{*}{$\begin{array}{c}\text { Erosi } \\
\text { (Ton/h } \\
\text { a/th) }\end{array}$} \\
\hline & & & & & Klei & Pasir & & & & & & & & & & \\
\hline 1 & & & & & & 55,72 & 0,91 & & & & & & 0,43 & & & \\
\hline & $120 N$ & $\mathrm{~N}$ & 10 & $\mathrm{~N}$ & 17,4 & & $\mathrm{~N}$ & 55,83 & $\mathrm{~N}$ & $107,59 \mathrm{~F}$ & R 5,48 & $3 \mathrm{~N}$ & $\mathrm{~N}$ & $386 \mathrm{~N}$ & & $13,24 R$ \\
\hline 2 & & & & & & 53,47 & 0,95 & & & & & & 0,18 & & $36 \mathrm{~N}$ & \\
\hline & 1081 & $\mathrm{~N}$ & 10 & $\mathrm{~N}$ & 20,46 & $\mathrm{~N}$ & $\mathrm{~N}$ & 55,81 & $\mathrm{~N}$ & $17,12 \mathrm{P}$ & R 5,20 & $\mathrm{ON}$ & $\mathrm{N}$ & $446 \mathrm{~N}$ & & $140,76 \mathrm{R}$ \\
\hline 3 & 106 & $\mathrm{~N}$ & 10 & $\mathrm{~N}$ & 1706 & $\begin{array}{r}60,73 \\
B\end{array}$ & $\begin{array}{r}1,08 \\
N\end{array}$ & & $\mathrm{~N}$ & & & $1 \mathrm{~N}$ & $\begin{array}{r}0,30 \\
N\end{array}$ & & $6,5 \mathrm{~N}$ & $4868 \mathrm{~B}$ \\
\hline 4 & & & & & & 59,81 & 0,98 & & & & & & 0,06 & & $18 \mathrm{~N}$ & \\
\hline & 981 & $\mathrm{~N}$ & 10 & $\mathrm{~N}$ & 13 & & $\mathrm{~N}$ & 40,24 & $\mathrm{~N}$ & $28,12 \mathrm{~F}$ & R 5 & $9 \mathrm{~N}$ & $\mathrm{~N}$ & $373 \mathrm{~N}$ & & $36,62 \mathrm{R}$ \\
\hline 5 & 951 & $\mathrm{~N}$ & 5 & $\mathrm{~N}$ & 14,98 & $\begin{array}{r}54,27 \\
\mathrm{R}\end{array}$ & $\begin{array}{r}0,89 \\
N\end{array}$ & 57,00 & $\mathrm{~N}$ & & $n$ & $9 \mathrm{~N}$ & $\begin{array}{r}0,07 \\
\mathrm{~N}\end{array}$ & & & $90,01 R$ \\
\hline 6 & & & & & & & 0,72 & & & & & & 0,16 & & $1,8 \mathrm{~N}$ & \\
\hline & 901 & $\mathrm{~N}$ & 10 & $\mathrm{~N}$ & 12,296 & $2,73 R$ & $N$ & 61,50 & $\mathrm{~N}$ & $12,23 \mathrm{~F}$ & & $2 \mathrm{~N}$ & $N$ & $377 \mathrm{~N}$ & & $73,77 \mathrm{R}$ \\
\hline 7 & & & & & & 47,22 & 1,10 & & & & & & 0,11 & & $2,3 \mathrm{~N}$ & \\
\hline 8 & 16 & IN & 20 & $\mathrm{~N}$ & & $\begin{array}{r}R \\
66,34\end{array}$ & $\begin{array}{r}N \\
1,10\end{array}$ & & $\mathrm{~N}$ & & & $\mathrm{~N}$ & $\begin{array}{r}N \\
0,21\end{array}$ & & $6.5 \mathrm{~N}$ & $54,17 R$ \\
\hline & $110 \mathrm{I}$ & $\mathrm{N}$ & 15 & $\mathrm{~N}$ & 11,62 & $\begin{array}{r}R \\
66\end{array}$ & $N$ & 52,17 & $\mathrm{~N}$ & $183,39 \mathrm{~F}$ & R 5 & $\mathrm{~N}$ & $\begin{array}{r}N \\
0.17\end{array}$ & $409 \mathrm{~N}$ & & $33,08 \mathrm{R}$ \\
\hline 10 & 125 & $\mathrm{~N}$ & 10 & $\mathrm{~N}$ & 14,39 & $\begin{array}{r}R \\
55,62\end{array}$ & $\begin{array}{r}N \\
0.96\end{array}$ & 51,54 & $\mathrm{~N}$ & $12,23 \mathrm{~F}$ & & $5 \mathrm{~N}$ & $\begin{array}{r}N \\
0,37\end{array}$ & $410 \mathrm{~N}$ & & $14,32 \mathrm{P}$ \\
\hline 11 & 1051 & $\mathrm{~N}$ & 10 & $\mathrm{~N}$ & 10,7 & $\begin{array}{r}R \\
61,64\end{array}$ & $\begin{array}{r}\mathrm{N} \\
1.15\end{array}$ & 55,14 & $\mathrm{~N}$ & $92,92 \mathrm{~F}$ & & $3 \mathrm{~N}$ & $\begin{array}{r}\mathrm{N} \\
0.12\end{array}$ & $490 \mathrm{~N}$ & $2,3 \mathrm{~N}$ & $6,42 N$ \\
\hline & $112 \mathrm{I}$ & & 15 & $\mathrm{~N}$ & 12,52 & $\begin{array}{r}R \\
65,67\end{array}$ & $\begin{array}{r}N \\
085\end{array}$ & 50,00 & $\mathrm{~N}$ & $10,39 \mathrm{~F}$ & R 4,9 & $+\mathrm{N}$ & $\begin{array}{r}N \\
010\end{array}$ & $415 \mathrm{~N}$ & & $25,93 \mathrm{P}$ \\
\hline & & & 15 & $\mathrm{~N}$ & 14,6 & & $\mathrm{~N}$ & 59,52 & $\mathrm{~N}$ & $37,29 \mathrm{~F}$ & R 5,76 & $\mathrm{~N}$ & $\mathrm{~N}$ & $\mathrm{~N}$ & & $284,75 \mathrm{R}$ \\
\hline 13 & 951 & & 15 & $\mathrm{~N}$ & 10.94 & $\begin{array}{r}47,74 \\
R\end{array}$ & $\begin{array}{r}1,09 \\
N\end{array}$ & 49,54 & $\mathrm{~N}$ & $103.92 \mathrm{~F}$ & R 5.40 & $\mathrm{~N}$ & $\stackrel{0,17}{N}$ & $410 \mathrm{~N}$ & $3,5 \mathrm{~N}$ & $156.70 \mathrm{R}$ \\
\hline
\end{tabular}

R: rusak, N: tidak rusak.

Tabel 3. Penilaian kerusakan tanah berdasarkan presentase frekuensi relatif

\begin{tabular}{llll}
\hline No. & Parameter & $\begin{array}{l}\text { Frekuensi Relatif } \\
\text { Kerusakan Tanah (\%) }\end{array}$ & Skor Frekuensi Relatif \\
\hline 1 & Ketebalan solum & 0 & 0 \\
2 & Kebatuan permukaan & 0 & 0 \\
3 & Tekstur & 92,31 & 4 \\
4 & Berat volume & 0 & 0 \\
5 & Porositas total & 0 & 0 \\
6 & Permeabilitas & 100 & 4 \\
7 & pH H $\mathrm{H}_{2} \mathrm{O}$ & 0 & 0 \\
8 & DHL & 0 & 0 \\
9 & Redoks & 0 & 0 \\
10 & Jumlah mikrobia & 0 & 0 \\
& Jumlah Skor & & $8^{*}$ \\
\hline
\end{tabular}

Keterangan: *Status Kerusakan Tanah termasuk Rusak Ringan (R.I).

Dugaan potensi kerusakan tanah di Kecamatan Selo yaitu tergolong dalam kelas potensi kerusakan sedang (PR.III) dan tinggi (PR.IV). Namun berdasarkan hasil verifikasi lapangan diperoleh hasil bahwa status kerusakan tergolong dalam status Rusak Ringan (R.I). SPL 1, SPL 2, SPL 7, dan SPL 9 yang tergolong kelas potensi kerusakan sedang memiliki jenis tanah Entisol dan Andisol dengan kemiringan lereng 9-15\%, penggunaan lahan sawah dan tegalan, serta curah hujan $2000-4000 \mathrm{~mm} / \mathrm{tahun}$. SPL 3, SPL 4, SPL 5, SPL 6, SPL 8, SPL 10, SPL 11, SPL 12, dan SPL 13 tergolong potensi kerusakan tinggi yang didominasi dengan jenis tanah Andisol, kemiringan $16-25 \%$ sampai $>40 \%$, curah hujan 3000 $4000 \mathrm{~mm} /$ tahun, serta penggunaan lahan kebun dan tegalan Jenis tanah wilayah penelitian didominasi oleh tanah Andisol dan Entisol yang termasuk dalam kategori potensi rusak tinggi sampai sangat tinggi, akan tetapi hasil verifikasi lapangan diperoleh nilai kedalaman solum lebih dari $90 \mathrm{~cm}$ yang berarti bahwa kedalaman solum berada di atas ambang kritis sehingga tidak tergolong rusak.

Rajamuddin (2009) menyebutkan bahwa keadaan lingkungan dimana tanah itu terbentuk dan adanya akibat saling tindak antara faktor dan proses pembentukan tanah yang bersangkutan sangat mempengaruhi kedalaman solum tanah. Bahan induk sebagai salah satu faktor pembentukan tanah berpengaruh terhadap kedalaman solum tanah. Wilayah penelitian berada di dekat gunung berapi 
dengan didominasi oleh jenis tanah Andisol. Bahan induk yang terdiri dari kumulatif deposit abu vulkan berpengaruh pada solum tanah yang dalam pada tanah-tanah tersebut. Solum tanah yang cukup dalam baik untuk perakaran tanaman karena pertumbuhan akar tanaman tidak terganggu sehingga tanah wilayah penelitian dapat dikatakan baik untuk pertanaman.

Hasil verifikasi lapangan pengukuran kelerengan lokasi sampel tersebar mulai 11-55\%. SPL 1, SPL 2, SPL 7, SPL 9 memiliki kemiringan lereng berturutturut $11,15,12$, dan $11 \%$ tergolong dalam potensi kerusakan ringan. Sedangkan untuk SPL lainnya yang memiliki tergolong dalam potensi rusak tinggi, akan tetapi hasil verifikasi lapangan menunjukkan penggunaan lahan SPL untuk hutan produksi dengan vegetasi rumput gajah dan semak. Semakin banyak lahan yang tertutup, kerusakan tanah akan semakin kecil dan sebaliknya lahan yang semakin terbuka akan menyebabkan tanah memiliki potensi kerusakan yang besar.

Hasil verifikasi lapangan menunjukkan mayoritas penggunaan lahan lokasi sampel adalah tegalan. Penggunaan lahan tegalan termasuk dalam kelas potensi kerusakan sangat tinggi. Hal ini disebabkan karena semakin banyak lahan yang terbuka, kerusakan tanah akan semakin besar. Hasil penelitian Sonder et al. (2002) di Kolumbia Bagian Selatan, mengemukakan bahwa erosi pada lahan yang ditanami singkong lebih tinggi dari lahan yang ditumbuhi semak belukar, erosi tahunan pada lahan pertanian singkong meningkat empat kali lebih besar dari penggunaan lahan semak belukar.

Akan tetapi jenis vegetasi, tipe pengelolaan dan langkah-langkah konservasi yang diterapkan yang terkait erat dengan sifat tanah akan mempengaruhi potensi kerusakan tanah. Penggunaan lahan untuk tegalan telah dilakukan tindakan konservasi seperti dibuat teras bangku. Hal ini sejalan dengan Majule (2003) yang mengemukakan bahwa erosi tanah merupakan fungsi dari penggunaan lahan. Pembuatan teras bangku ini dapat mengurangi bahaya erosi, sehingga dapat menurunkan potensi kerusakan tanah.

\section{KESIMPULAN DAN SARAN}

\section{Kesimpulan}

1. Potensi kerusakan tanah di Kecamatan Selo terbagi menjadi 2 kelas yaitu: kelas potensi kerusakan tinggi (PR IV) pada SPL 3, SPL 4, SPL 5, SPL 6, SPL 8, SPL 10, SPL 11, SPL 12, dan SPL 13 dengan persentase luas wilayah yaitu $1.988,8$ ha atau $32,8 \%$ dan kelas potensi kerusakan sedang (PR III) yaitu SPL 1, SPL 2, SPL 7, dan SPL 9 dengan persentase luas wilayah yaitu 1439,3 ha atau $23,8 \%$.

2. Status kerusakan tanah di Kecamatan Selo tergolong Rusak Ringan (R.I) dengan luas $3.356,29$ ha yang terbagi menjadi 3.296,97 ha atau $54,36 \%$ dengan faktor pembatas tekstur dan permeabilitas dan 59,32 ha atau $0,98 \%$ dengan faktor pembatas permeabilitas. SPL 1 dan SPL 313 tergolong dalam kelas status rusak ringan dengan faktor pembatas tekstur dan permeabilitas, SPL 2 tergolong kelas status rusak ringan dengan faktor pembatas permeabilitas.

\section{Saran}

Saran yang dapat diberikan untuk penelitian selanjutnya adalah data base informasi berbagai parameter kerusakan tanah di Kecamatan Selo dapat digunakan sebagai acuan dalam pengelolaan lahan yang berkelanjutan untuk menjaga kelestarian tanah serta penambahan fraksi klei pada tanah dapat mengurangi dominasi fraksi pasir dan penambahan bahan organik dapat dilakukan untuk mengurangi kecepatan infiltrasi.

\section{DAFTAR PUSTAKA}

BPS [Badan Pusat Statistik]. 2013. Kecamatan selo dalam angka 2013. Badan Pusat Statistik Kabupaten Boyolali. Boyolali.

Hanafiah KA. 2005. Dasar-Dasar IImu Tanah. Jakarta (ID): PT Raja Grafindo Persada.

Majule AE. 2003. Impact of land use/landcover changes on soil degradation and biodiversity on the slopes of mount Kilimanjaro. Tanzania. Land Use Change Impact and Dynamics Working. Tanzania: Institute of Resource Assessmen University of Dar es Salaam.

Menteri Negara Lingkungan Hidup. 2009. Peraturan Menteri Negara Lingkungan Hidup Nomor 17: Pedoman Penentuan Daya Dukung Lingkungan Hidup Dalam Penataan Ruang Wilayah. Kementerian Negara Lingkungan Hidup. Jakarta.

Menteri Negara Lingkungan Hidup. 2006. Peraturan Menteri Negara Lingkungan Hidup Nomor 07, Jakarta (ID): Tata Cara Pengukuran Kriteria Baku Kerusakan Tanah untuk Produksi Biomassa.

Pemerintah RI. 2000. Peraturan Pemerintah Republik Indonesia Nomor 150, Jakarta (ID): Pengendalian Kerusakan Tanah untuk Produksi Biomasa.

Rajamuddin UA. 2009. Kajian tingkat perkembangan tanah pada lahan persawahan di desa kaluku tinggu kabupaten donggala sulawesi tengah. J Agroland 16(1): 45-52.

Rajiman. 2014. Potensi kerusakan tanah. Yogyakarta (ID): STTP Yogyakarta.

Siradz SA. 2006. Degradasi lahan persawahan akibat produksi biomassa di Yogyakarta. J Ilmu Tanah dan Lingkungan. 6(1): 47-51.

Siregar NA, Sumono, Achwil PM. 2013. Kajian permeabilitas beberapa jenis tanah di lahan percobaan kwala bekala usu melalui uji laboratorium dan lapangan. J Rekayasa Pangan dan Pert. 1(4): 138-143.

Sonder K, Müller-Sämann K, Hilger T, Leihner D. 2002. Erosion control and prediction in cassava based cropping systems in the southern andean region of colombia. Beijing $(\mathrm{CHN})$ : ISCO Conference.

Subroto. 2010. Kajian karakteristik tanah bagi ubi cilembu di nagarawangi rancakalong sumedang. J. IImu Tanah dan Lingkungan 10 (1): 26-34. 
Agrosains 18(1): 6-11, 2016; ISSN: 1411-5786

Suriadi A, Nazam M. 2005. Penilaian kualitas tanah berdasarkan kandungan bahan organik (kasus di kabupaten bima). Nusa tenggara Barat: Balai Pengkajian Teknologi Pertanian.
Yulnafatmawita, Luki, Yana. 2007. Kajian sifat-sifat fisika tanah beberapa penggunaan lahan di bukit gajabuih kawasan hutan hujan tropika gunung gadut padang. J Solum 4(2): 49-61. 